\title{
Tomasz Czapiewski*
}

\section{THE (PARA)DIPLOMACY OF SCOTLAND TOWARDS ASIAN COUNTRIES}

\section{Introduction}

This article aims at presenting the activity of Scotland as a sub-state entity with reference to the field of its foreign policy, one that possesses a wide degree of autonomy towards the United Kingdom authorities.

In the process of the devolution ${ }^{1}$ in the years 1997-1999 many sectors of the British public policy were transferred to the newly created bodies such as the Scottish Parliament and the Scottish Government (referred to as the Scottish Executive in the first years after the devolution). ${ }^{2}$ The domains reserved for the authorities in London have been determined in Annex 4 and Annex 5 of the Scotland Act. ${ }^{3}$ The enumerations included therein are extremely detailed, although not always consistent. What is particularly important from the point of view of the purposes of this article, is that the so-called "reserved matters" concern the United Kingdom foreign policy and international trade, with the exception of the

* dr Tomasz Czapiewski, adiunkt w Instytucie Politologii i Europeistyki Uniwersytetu Szczecińskiego, e-mail: tomekczapiewski@gmail.com.

1 Devolution is a process of the delegation of powers by the central government in the United Kingdom to the bodies representing the territories of Scotland, Wales and Northern Ireland.The characteristics of devolution include: 1) asymmetry, manifested in the lack of regional bodies in England; 2) supremacy of the Parliament of the United Kingdom, because devolution may be revoked at any time; 3) direct elections to the legislative bodies in Scotland, Wales and Northern Ireland.

2 Cf. T. Czapiewski, Kształtowanie się systemu politycznego Szkocji. Szczecin: Wydawnictwo Naukowe Uniwersytetu Szczecińskiego 2011.

3 Scotland Act 1998, http://bit.ly/16ysJDX. Accessed: 4.02.2015. 
implementation of the European Union's regulation and the European Convention on Human Rights.

In this context, however, it should be taken into account that the concept of foreign policy has significantly changed in recent decades. ${ }^{4}$ There is, in particular, a strong dispersal of foreign policy in the vertical and horizontal direction. In the first case, this means the phenomenon of the increased activity of entities other than the state (international organizations, regions) in the field of foreign policy. The horizontal dispersal should be understood as an extension of the activity types generally referred to as foreign policy. However, the strategies of the sub-state organizations such as Scotland influencing relations with actors outside the state (in this case, the UK) can be divided into two categories: intrastate and external. ${ }^{5}$ As regards the former category, the "region" does not work alone with foreign partners, but tries to shape the state preferences and actions in a way that takes into account regional interests. If a state has a strong position in the international arena and is open to the signals from outside, such a strategy can turn out most effective. This article, however, analyzes the activity undertaken in the external strategy, i.e. without the direct involvement of state institutions. Michael Tatham's research clearly demonstrates that when the opposition party comprises the government at the sub-state level, bypassing state is more frequent. Adversely, devolution of powers increases the frequency of cooperation with state government. ${ }^{6}$

The term most often used to describe the above depicted phenomenon is paradiplomacy. ${ }^{7}$ Foreign actions undertaken by the regional government are a specific cooperation type, treated as an element of a state's foreign activity, that is, one aspect of its contemporary foreign policy (hence other terms such as: "paradiplomacy," "microdiplomacy," "protodiplomacy," "diplomacy from be-

4 J.T. Mathews, "Power Shift." Foreign Affairs Vol. 76, No. 1, 1997: 50.

5 Cf. C. Jeffery, "Sub-National Authorities and European Domestic Policy." The Regional Dimension of the European Union. Ed. C. Jeffery. London: Frank Cass 1996; C. Jeffery, "SubNational Mobilization and European Integration: Does it Make Any Difference?" Regions and Regionalism in Europe. Ed. M. Keating. Cheltenham: Edward Elgar 2004: 443-466.

6 M. Tatham, "With or Without You? Revisiting Territorial State-Bypassing in EU Interest Representation.” Journal of European Public Policy Vol. 17, No. 1, 2010: 76-99.

7 In the scientific literature the notion of paradiplomacy is sometimes used in different sense-as assigning diplomatic tasks to people outside the circle of diplomats. Cf. J. Sutor, Prawo dyplomatyczne i konsularne. Warszawa: LexisNexis 2006. 
low," social diplomacy," "civil diplomacy," or "small foreign policy"). ${ }^{8}$ Although a sub-state entity is sovereign and, as such, does not conduct foreign policy in the strict sense, it can be engaged in many forms of international activities, some of them identical with the actions undertaken by a state within the realm of foreign policy. Alexander Kuznetsov defines paradiplomacy as a "form of political communication for reaching economic, cultural, political, or any other types of benefits, the core of which consists in self- sustained actions of regional governments with foreign governmental and non- governmental actors."9 Paradiplomacy can be regarded not only as the name of a certain category, but also as a research approach allowing to explain regions' autonomous diplomatic practices and taking into consideration the strong political connotations. ${ }^{10}$

According to Panayotis Soldatos, the external activities of sub-state authorities contain the essential elements of the foreign policy such as: goals, strategies, tactics, institutions, decision making process, instruments, and outputs. ${ }^{11}$ The paradiplomacy is a process where the growing number of sub-state territorial actors seek a more prominent international presence, a demand often made by substate nations to access international relations directly without the mediation of the central state organs. ${ }^{12}$ It is also an exceptional phenomenon as sovereign states still often regard this international activity as their exclusive domain, ergo, see any activity of subnational actors as a dangerous intrusion. Equally frequently, sub-state governments and local authorities do not require the intervention of central bureaucracies and elites. ${ }^{13}$

8 W. Modzelewski, A. Żukowski, "Kategoria pogranicza w politologii. Aspekty teoretyczne i praktyczne." Pogranicze. Polish Borderlands Studies No. 1, 2013: 35-35; K. Tomaszewski, Regiony w procesie integracji europejskiej. Kraków: Oficyna Ekonomiczna Grupa Wolters Kluwer 2007: 129-135; K. Szmigiel, Regionalne po co i z kim? Relacje międzynarodowe polskich województw. Warszawa: Geoprofit 2009: 47.

9 A. Kuznetsov, Theory and Practice of Paradiplomacy: Subnational Governments in International Affairs. New York: Routledge 2015: 30-31.

10 F. Dickson, "The Internationalisation of Regions: Paradiplomacy or Multi-Level Governance?” Geography Compass Vol. 8, No. 10, 2014: 689-700.

11 P. Soldatos, "An Explanatory Framework for the Study of Federated States as Foreignpolicy Actors." Federalism and International Relations. The Role of Subnational Units. Eds. H. Michelmann, P. Soldatos Oxford: Oxford University Press 1990: 44-49.

12 F. Aldecoa, M. Keating (eds.), Paradiplomacy in Action. London: Frank Cass 1999 and D.D. Laitin, "National Identities in the Emerging European State." Minority Nationalism and the Changing international Order. Eds. M. Keating, J. McGarry. Oxford: Oxford University Press 2001: 84-113.

13 L. Moreno, "Local and Global: Mesogovernments and Territorial identities." Nationalism and Ethnic Politics Vol. 5, No. 3-4, 1999: 61-75. 
Protodiplomacy can be recognized as the highest development level for paradiplomacy concerning the regions with clearly defined separatist ambitions. ${ }^{14}$ Protodiplomacy aims at strengthening foreign partners' belief in a region's credibility and can therefore be helpful e.g. in creating a favorable attitude towards the region's plans as to the creation of its own state, potential recognition of its independence and swift establishment of intensive relations. In the case of Scotland, these criteria correspond to the greatest extent to the position of the Scottish government in respect of the convicted terrorists from Lockerbie. Releasing them from prison, despite the pressure exerted by London, was epidictic presenting Scotland as a separate entity with the individual identity based on a specific set of values, laws and customs. ${ }^{15}$ In fact, however, the factors that distinguish protodiplomacy from paradiplomacy often have only a symbolic value.

The character of the relationship between the regional and national level in the field of foreign policy is of particular importance when paradiplomacy is at stake. The literature on the subject quotes four models of such relationships that this article will present as the conflict, domination, complementing, and discretion. In the conflict model, the level of regional policy is perceived via the central government as contrary to the interests of the state. Regarding domination, authorities at the regional level exclusively implement the recommendations of the central government. In the case of the complementing model, the central government calls for activity and self-reliance in shaping specific aspects of the foreign policy such as e.g. the cross-border cooperation. In the discretion model, the central government does not interfere in the international relations activities of the regional-level government. Soldatos also distinguishes the favourable conditions of paradiplomacy such as the leaders' personality, historical and cultural ingredients, socio-political climate, important geographic position and resources, supportive paradiplomacy of the federal unit cities, and legislation promoting, for example, foreign investment. ${ }^{16}$

14 R. Palmer, Devolution, asymmetry and Europe: multi-level governance in the United Kingdom. Brussels: Peter Lang 2008: 27-30.

15 D. Kenealy, "Commercial Interests and Calculated Compassion: The Diplomacy and Paradiplomacy of Releasing the Lockerbie Bomber.” Diplomacy \& Statecraft Vol. 23, No. 2, 2012: 555-575.

16 P. Soldatos, op.cit., p. 46. 
Foreign activities of the regions focus on achieving the objectives in the fields of economy, culture and politics..$^{17}$ The economic aims are: attracting foreign investors and multinational companies, as well as searching for new export markets. It is a derivative of the emergence of the global competitive market. In the political layer, the basis is to show the distinct identity, so protodiplomacy can be recognized as a paradiplomacy focusing on the political aims. Factors influencing the direction and content of paradiplomacy can have local, state and foreign nature. Michael Keating points at the fact that unlike the foreign policy of states, paradiplomacy does not seek to represent broad general interests or to be comprehensive. Regions are not able or even do not have to possess the one definition of regional interest and to implement it in unified and coherent manner. ${ }^{18}$

Foreign activities of the regions are primarily determined by the constitutional regulations. In some Federal States, regions have competences in the field of foreign policy provided directly by the Constitution. ${ }^{19}$ Horizontal dispersal of the previously mentioned foreign policy allows regions to conduct activities in this area even in the absence of such regulations.

Regional governments usually face problems of limited financial and institutional capacity. It is therefore particularly important for the effectiveness of the paradiplomatic actions to carefully select priorities. Primarily, they should not be too numerous. This applies to both targeted areas, as well as established goals. It often becomes necessary to use the support of state institutions, mainly various diplomatic missions, both in other states and intergovernmental organizations. ${ }^{20}$

The European integration process, in particular the cross-border cooperation, has contributed to the development of the paradiplomacy phenomenon. In fact, devolution can be to some extent considered as a manifestation of the process developed in the West European democracies and named by George Sorensen as the transformation from the modern state into the postmodern state. In this pro-

17 C. Jeffery, "Scotland's European and International Policy." Foreign Policy of Constituent Units at the Beginnings of 21st Century. Ed. F. Requejo. Barcelona Institut d'Estudis Autonňmics (Catalunya) 2010: 111; A. Lecours, "Political Issues of Paradiplomacy: Lessons from the Developed World." The paper presented in the Clingendael Discussion Papers in Diplomacy at the Clingendael Institute in the Hague in 2008, http://bit.ly/1908Y9t. Accessed: 7.02.2015. Lecours sees the second layer of paradiplomacy in a broader way as a cooperation (cultural, educational, technical, technological and others).

18 M. Keating, "Paradiplomacy and Regional Networking...3." The paper presented in 2000 at the conference entitled "Forum of Federations: an International Federalism," http://bit. ly/1EgcLsH. Accessed: 30.01.2015.

19 C. Jeffery, op.cit., 115.

20 S. Wolff, "Paradiplomacy: Scope, Opportunities and Challenge." The Bologna Center Journal of International Affairs Vol. 10, 2007. 
cess, the following three phenomena can be distinguished: the economic activity conducted within the framework of network structures, nation state government replaced by the multi-level governance, and weaker homogenous national identity. ${ }^{21}$

This article analyzes the activity of a paradiplomatic nature of the Scottish political institutions towards the countries within the Asian continent via studying the government documents, statistics, reports and other documents published by parliamentary committees as well as the information from the state agencies and press releases. Apart from highlighting the actions of the First Minister as the most important actor in the political system of Scotland, this article pays special attention to the actions of the entities such as the European and External Relations Committee of the Scottish Parliament and the Cabinet Secretary for Culture, Europe and External Affairs responsible for Scotland's international activity ${ }^{22}$.

\section{Scottish paradiplomacy in Asia - case studies}

The foundation for the activities of the Scottish institutions in the international arena were laid by the Scottish Government in 2008 in the "International Framework," the project to be subsequently changed in $2012 .{ }^{23}$ The Framework has stated the following objectives: creating the image of Scotland as a successful country, benefiting from opportunities through the promotion of Scottish entrepreneurs abroad, attracting direct foreign investment, ensuring that Scottish interests are taken into account in the formation of European Union law and, finally, proving that Scotland is "a great place to live, learn, visit, work, do business and invest."

The year 2007 saw a radical change in the Scottish political system taking place after the election to the Scottish Parliament won by the Scottish National Party. The election has also resulted in the partial change in the area of foreign policy. The relations with the European Union and the Member States have continued to be crucial. The European activity has been focused on the interregional cooperation to a lesser extent than previously, for example Scotland has become

${ }^{21}$ G. Sorensen, "Globalization and the nation-state." Comparative Politics. Ed. D. Caramani. Oxford: Oxford University Press 2008: 613.

22 It must be emphasized that the term ,external affairs,” not „,foreign affairs” is used. It is linked to the previously mentioned articles in the Scotland Act 1998.

23 The Scottish Government. Scotland's International Framework 23 X 2012, Edinburgh: APS Group Scotland 2012, http://bit.ly/1zDvK0W. Accessed: 10.05.2014. 
less engaged in the works of RegLeg (the Conference of European Regions with Legislative Power). The smaller European countries, in particular from the area of the Northern Europe, such as Sweden, Norway, Iceland or Ireland, have become Scotland's preferred partners. The increased activity outside the European continent, also within the framework of the development assistance, has been a noticeable trend. ${ }^{24}$

In the Asia region the Scottish government treats China as the most important partner, this being validated by the fact of Scotland having one of her three independent diplomatic missions (Brussels, New York and Beijing) placed in China. Back in 2006, at the time of the government coalition of the Scottish Labour Party and the Scottish Liberal Democrats, the government published the document entitled "Scotland's strategy for stronger engagement with China" defining the strategy's ten basic objectives and indicators for a period of five years. This strategy was modified in 2008. ${ }^{25}$ In 2012, the Scottish Government published the third edition of the strategy in question entitled "Working with China: A Five Year Strategy for Engagement between Scotland and the People's Republic of China."

The China Strategy comprises the following four guiding principles intended to underpin Scotland's relations with China: Securing Sustainable Economic Growth, Understanding of Culture, Increasing Scotland's Influence and Respect for Human Rights, and the Rule of Law (by “supporting China's process of modernisation and internal reform and the need to balance the demands of economic development with social justice"). ${ }^{26}$ The Strategy also outlines the four key priorities for Scotland as follows: ${ }^{27}$ increasing trade opportunities for the Scottish business in China and encouraging more Chinese investment in the Scottish industry and infrastructure; expanding and deepening Scotland's education links with China; increasing collaboration in the research and development between China and Scotland; promoting an innovative and creative Scotland through deeper cultural exchanges and sporting links with China and Hong Kong Special

24 C. Jeffery, op.cit., p. 112.

25 The European and External Relations Committee Report. Inquiry into the Scottish Government's China Plan. 3rd Report, 2009 (Session 3), SP Paper 326, http://bit.ly/1ztI3g3. Accessed: 7.02.2015.

26 The Scottish Government. Working with China. A Five Year Strategy for Engagement between Scotland and the People's Republic of China. Edinburgh: APS Group Scotland 2012: 3-4, http://bit.ly/1v8ZKfz. Accessed: 7.02.2015.

27 Ibidem. 
Administrative Region; and promoting Scotland as a destination of choice for Chinese tourists.

In the catalogue of the so-called Strategy levers the following should be mentioned: utilizing Ministerial visits to China to include trade delegations and encourage high-level reciprocal visits to Scotland; making greater use of alumni and Scottish expatriate networks in China; encouraging more researcher exchanges at all levels, or even establishing "links with the Chinese Golf Association and the Shanghai Golf Association to develop an exchange programme involving junior golfers." 28

The exports from Scotland to China in the years 2012 and 2013 were the largest in history, reaching the level of 560 million pounds. This latter number constituted an increase by $30 \%$ as compared to the previous year. China's participation in the Scottish exports increased in years 2007-2012 from $1.9 \%$ to $2.6 \%$. This augmentation resulted, mainly, from the growth of food exports (mostly salmon), beverages (primarily, whisky), and machinery and transport equipment.

Moreover, Chinese tourists made the 29 million pounds worth of direct contribution to the Scottish economy between 2010-2012. ${ }^{29}$ There was a strong upswing in this area a few years ago. Between the years 2008 and 2010 approximately 10000 Chinese tourists visited Scotland, while between the years 2012 and 2013 this number amounted, on the average, to $31000 .{ }^{30}$ However, in comparison with the Western European and the North American countries, these numbers are still not impressive. Tourists from Asian countries are not even included in top ten list of tourists visiting Scotland each year, whereas e.g. the number of tourists from Spain, ranked 10th on the list, approximates $91000 .{ }^{31}$

Currently as many as five Scottish universities: Edinburgh, Glasgow, Aberdeen, Strathclyde and Heriot-Watt have their own Confucius Institutes. They are centers promoting both educational, economic, and cultural ties between Scotland and China and, first and foremost, the Chinese language. They were set up with government backing and partnered with the universities in China. ${ }^{32}$

28 Ibidem.

29 The Visit Scotland Organization has even prepared a profile of Chinese tourist in Scotland. The majority of Chinese visitors only come to Scotland as part of organised tours or on business trips. They belong in the highest spenders (usually more than US or European tourists).

${ }_{30}$ Visit Britain. Trends in visits, nights, and spend to Scotland by visitors from overseas 2013, http://bit.ly/1FjuArO. Accessed: 7.02.2015.

${ }_{31}$ Visit Scotland. Scotland. The Key Facts on Tourism in 2013, http://bit.ly/1ztnMqO Accessed: 7.02.2015.

32 Confucius Institute for Scotland, History, http://bit.ly/1zXejrV. Accessed: 15.02.2015. 
The priority of the Scottish relations with China could be demonstrated by the demeanour of the Scottish First Minister Alex Salmond on two occasions. Firstly, the Minister referred to the situation when two Chinese teachers from the Confucius Institutes in Scotland have been denied their Scottish visas as the UK's "sabotage." 33 The refusal was probably due to the tense diplomatic situation between the United Kingdom and China in 2012-2013. Secondly, Salmond refused meeting the Dalai Lama when he visited Scotland. ${ }^{34}$ The Minister explained this refusal in an unconvincing way indicating that the Dalai Lama had come to Scotland as a religious leader, not a politician. Similarly, when asked about the status of Tibet and Taiwan in the context of the Scottish referendum, Salmond pointed out that the Scottish case was defined by the agreement signed between Scotland and the UK and "should not be compared with others."

However, the Scottish Government's policy is also criticized. Philip Morgan, a former secretary of the Scottish Affairs in the British Embassy in Beijing, criticized the Scottish strategy towards China for its lacking an integrated approach to the implementation of specific policies, especially in the context of achieving the objectives set in the Strategy. ${ }^{35}$ During the meeting of the Scottish Parliament Committee he pointed to the fact that the Strategy did not define the risk factors that could interfere with the achievement of objectives, which is particularly important as in many areas the China Strategy is based on assumptions regarding the actions of the external entities over which the Scottish Government has little control. Furthermore, by no means does the Strategy refer to the issue of financing the plan's implementation, and neither does it specify any minimum budget or assign resources. It also lacks an effective system of monitoring and provides few specific assumptions concerning regular visits of the Government members in China. According to Morgan, an increasing economic exchange with China requires radical steps, and those are not included in the Plan. The critical feedback, although from a different perspective, was also provided by Denis Taylor, former head of the Scottish Development International agency. ${ }^{36}$ Taylor estimated that

33 D. Sevastupolo, "Alex Salmond Slams UK Decision on Visa of 2 Chinese Teacher." The Financial Times 6.11.2013, http://on.ft.com/1ztd5o7. Accessed: 7.02.2015.

34 K. Peterkin, "Record 'Proves Alex Salmond Kowtowed over Dalai Lama' Visit." The Scotsman 9.08.2012, http://bit.ly/1EOrBdm. Accessed: 7.02.2015.

35 The European and External Relations Committee. Written Evidence From Philip Morgan (Ex First Secretary (Scottish Affairs)), http://bit.ly/lyjDHUu. Accessed: 3.02.2015.

36 C. Donald, "International Trade Expert Queries Value of Scotland's China Plan." The Herald 6.01.2013, http://bit.ly/1yjDHUu. Accessed: 3.02.2015. 
a real impact of the China Strategy on the Scottish economy amounts to as much as $0.05 \%$ of the Scottish GDP.

Pakistan and India have been Scotland's other major Asian partner. In September 2010 the Scottish Government published both the "India Plan"37 and the "Pakistan Plan"38 whose priorities were formally similar to those making the China Strategy operative: culture, business, trade and investment, and tourism. What requires emphasizing is exactly the non-accidental order of priorities. For example, the Pakistan Plan is mostly dedicated to the support of cultural activities of the Pakistani community in Scotland aimed at increasing Scots' awareness as regards the Pakistani culture and art.

The Scottish-Pakistani relations were mainly present in the media in two controversial cases. Firstly, with regard to the so-called Tartan Taliban, when Dundee-born James McLintock became Muslim and mujahedeen fighter, and was even close to becoming the leader of terror training camps in Afghanistan (the Guantanamo Bay documents called him the "al-Scotlandi"). The second mention of these relations was associated with the case of the British citizen Mohammed Ashgar who spent most of his life in Scotland only to become a patient of a closed psychiatric hospital diagnosed with paranoid schizophrenia in 2011. After his release from the facility he went to Pakistan where he was later sentenced to death for blasphemy - Ashgar wrote letters in which he called himself Islamic prophet Muhammad. ${ }^{39}$

In September 2012 Humza Yousuf (his mother was from Kenya and his father - from Pakistan) became Minister of External Affairs and International Development in the Scottish Government. ${ }^{40}$ Yousuf visited Pakistan in 2013 promoting educational projects on helping young women from poor families. ${ }^{41}$ Similar projects supporting the learning of the English language and the education in the agriculture were also submitted to the communities of Bangladesh and India. In

37 The Scottish Government. India Plan. Edinburgh: APS Group Scotland 2010, http://bit. ly/1yL9o8w. Accessed: 7.02.2015.

38 The Scottish Government. Pakistan Plan. Edinburgh: APS Group Scotland 2010, http:// bit.ly/1yUtiz3. Accessed: 7.02.2015. However, both the Pakistan Plan and the India Plan have not been published as official government documents and have been limited to some rather general information on the website of the government. Comparing both plans, it is reasonable to say that the Pakistan Plan is drawn up on a rudimentary level only.

39 M. McLauglin, "PM ‘Concern' over Scot on Death Row for Blasphemy.” The Scotsman 30.01.2014, http://bit.ly/1DBbso5. Accessed: 30.01.2015.

40 Since 2014 the position has been that of the Minister for Europe \& International Development.

${ }^{41}$ It was the first visit of the Scottish Minister in Pakistan. "Scotland to Fund Malala Inspired Scholarship.” The Scotsman 20.10.2013, http://bit.ly/luo8DXr. Accessed: 6.02.2014. 
this context the complicated political career of Mohammed Sarwar - a representative of the Glasgow Central constituency in the Westminster Parliament between 1997-2010 on behalf of the Labour Party and the first Muslim MP (Member of Parliament) - is also worth mentioning. In 2010 the same constituency mandate was obtained by Sarwar's son, Anas Sarwar. In 2013 Mohammed Sarwar became Governor of the largest province of Pakistan, Punjab, and waived his British citizenship..$^{42}$

The importance of the educational cooperation with India was especially highlighted during the visit of the First Minister of Scotland in India in 2010 as approximately 4,000 students in Scotland come from India. ${ }^{43}$ In addition, India seems to be an attractive economic partner for Scotland, especially as a possible target for wind energy technology exports. Scotland is one of the pioneers in this area, and the extensive coastline of India appears as potentially substantial for the development of the energy source in question. ${ }^{44} \mathrm{~A}$ memorandum of understanding in this regard was signed during the Indian visit of Mike Russell, the then Minister for Culture, External Affairs and the Constitution, in 2009.

At the same time, a negative trend in the field of higher education could be observed. The number of Indian students in Scotland in the academic year 2011-2012 decreased by $25.8 \%$ as compared to the previous year. In the case of students from Pakistan, the decrease amounted to $24.9 \%$ and was a direct result both of the decisions of the UK Borders Agency to limit career possibilities for British universities graduates without the European Union's citizenship (the socalled "post study work route") and general constraints on immigration. This resolve encountering the criticism by the Scottish authorities at the same time evidenced the limits of Scotland's ability to shape policies without the state status. ${ }^{45}$ However, this negative trend did not turn in the subsequent years with noticeable stagnation or even further small declines. ${ }^{46}$ It is worth mentioning that the 2009

42 M. Kelly, “Pakistan Too Good to Miss.” The Scotsman 10.10.2012, http://bit.ly/1HT5eWR. Accessed: 30.09.2014. Sarwar resigned from his post in January, probably in consequence of his public statements criticizing the central government in the context of Barack Obama's visit to India; A. Manan, "Governor Punjab Chaudhry Sarwar Resigns after Making Anti-Govt Remarks." The Express Tribune 29.01.2015, http://bit.ly/1zxSIF5. Accessed: 3.02.2015.

43 "Education Link-up between Scotland and India Announced." The Scotsman 12.10.2010. http://bit.ly/lyBe5mf Accessed: 30.09.2014.

44 "Scotland and India Join Forces in Green Energy Drive." The Scotsman 14.10.2009, http://bit.ly/1A21mxn. Accessed: 7.02.2015.

45 C. Marshall, "Scots Universities Criticise UK Immigration Laws." The Scotsman 12.02. 2013, http://bit.ly/1A232XF. Accessed: 7.02.2015.

46 K. Duncan, "UK HE Enrollments: 3\% Growth Eclipsed by Fall in Indian Numbers." The Pie News 15.01.2015, http://bit.ly/ly4I5u4. Accessed: 7.02.2015. 
research indicated international students as having directly brought 188 million pounds a year to Scottish universities, and an additional 321 million to the entire Scottish economy.

The globalization effects and the incrementally growing importance of Asian countries can also be demonstrated by an analysis of one of the best-known Scottish economy sectors - the production of whisky. At present only about $1 / 4$ of companies based in Scotland are owned by the Scottish business with almost similar number of companies belonging to the Asian firms from Japan, Thailand, or Philippines. ${ }^{47}$ The presence of Scotland in the South Asian region has been assessed positively even in the report of the Commission of the United Kingdom Parliament. ${ }^{48}$

\section{Conclusions}

The actions undertaken by Scotland in the international arena allow for studying them within the bounds of paradiplomacy. Since 2007 the activities of the Scottish Government have shown specific symbolism referring both to building the image of Scotland and the possible independence and establishment of the Scotland state. In this latter case, the notion of the Scottish protodiplomacy is also justified as a methodological tool as Scottish authorities tried to act like "an aspiring state," creating the foundation for the future membership in the European Union. ${ }^{49}$

The most important target of Scotland's paradiplomatic activity in Asia is China. Together with the European Union and North America, China belongs to the priority areas of Scottish paradiplomacy. The paradiplomacy towards China considers economic objectives achieved, however, by different means, including cooperation in the fields of science, education, tourism, and even sports. The cultural objectives are present yet remain ancillary to the economic goals. The 2011-2013 statistics demonstrate the effectiveness of the adopted strategy as ex-

47 F. Hashemi, C. Macdonald. "Revealed: only a Quarter of Our Distilleries Are Owned by Scots Firms." The Herald 2.02.2015, http://bit.ly/1LIa0G4. Accessed: 3.02.2015.

48 The House of Commons Foreign Affairs Committee. Foreign Policy Considerations for the UK and Scotland in the Event of Scotland Becoming an Independent Country. The Sixth Report of Session 2012-13 Report together with the formal minutes, oral and written evidence 23.04.2013, http://bit.ly/1BUrpTK. Accessed: 4.02.2015.

49 After the independence referendum in Scotland held on September 18, 2014 where $55.30 \%$ of the voters were in favour of staying in the United Kingdom, this latter possibility has been postponed for decades. 
ports to China and the number of tourists from this country are strongly increased. On the other hand, the lack of progressing interest in the Scottish universities stems from factors beyond the control of the Scottish Government. There may be some doubts, however, about the consistent and almost complete avoidance of the human rights issues in the development of Scottish-Chinese relations.

Other parts of Asia are considered as lower priority, closer to the category of development assistance rather than intensification of mutual relations. Especially in the times of global economic turmoil China used to be far more important a direction as a country potentially helpful for different sectors of the Scottish economy with regards to economy- and prosperity building.

The motivations of the Scottish paradiplomacy towards Asian countries can be seen on the regional (e.g. the presence of the Pakistani and Indian minorities in Scotland), state (e.g. the historical conditions of the United Kingdom - Hong Kong relations), and external (e.g. China's strong position and economic potential) levels.

The relations between the regional and national levels (Scotland and the United Kingdom) can be studied as bridging the discretion and the complementing foreign policy models. The policy towards Asia shows few contradictions between the objectives on the central and regional levels. It also seems that the Whitehall government does not want to unduly restrict the Scottish paradiplomatic activities so as not to reinforce sentiments in the Scottish society that the current constitutional arrangements are inadequate and that Scotland needs to strive for independence, an advancement which involves, among others, the freedom to pursue her own foreign policy.

\section{WORKS CITED}

„Education Link-up between Scotland and India Announced.” The Scotsman 12.10.2010, http://bit.ly/1yBe5mf Accessed: 30.09.2014.

"Scotland and India Join Forces in Green Energy Drive." The Scotsman 14.10.2009, http://bit.ly/1A21mxn. Accessed: 7.02.2015.

"Scotland to Fund Malala Inspired Scholarship." The Scotsman 20.10.2013, http://bit. ly/1uo8DXr. Accessed: 6.02.2014.

Aldecoa, Francisco. Keating, Michael (eds.). Paradiplomacy in Action. London: Frank Cass 1999.

Confucius Institute for Scotland. History, http://bit.ly/1zXejrV. Accessed: 15.02.2015. 
Czapiewski, Tomasz. Kształtowanie się systemu politycznego Szkocji. Szczecin: Wydawnictwo Naukowe Uniwersytetu Szczecińskiego 2011.

Dickson, Francesca. "The Internationalisation of Regions: Paradiplomacy or Multi-level Governance?” Geography Compass Vol. 8, No. 10, 2014.

Donald, Colin. "International Trade Expert Queries Value of Scotland's China Plan.” The Herald 6.01.2013, http://bit.ly/1yjDHUu. Accessed: 3.02.2015.

Duncan, Katie. "UK HE Enrollments: 3\% Growth Eclipsed by Fall in Indian Numbers." The Pie News 15.01.2015, http://bit.ly/1y4I5u4. Accessed: 7.02.2015.

Hashemi, Franchesca, Calum Macdonald. "Revealed: only a Quarter of Our Distilleries Are Owned by Scots Firms." The Herald 2.02.2015, http://bit.ly/1LIa0G4. Accessed: 3.02.2015.

Jeffery, Charlie. "Scotland's European and International Policy." Foreign Policy of Constituent Units at the Beginnings of 21st Century. Ed. F. Requejo. Barcelona: Institut d'Estudis Autonňmics (Catalunya) 2010.

. "Sub-National Authorities and European Domestic Policy." The Regional Dimension of the European Union. Ed. C. Jeffery. London: Frank Cass 1996.

. "Sub-National Mobilization and European Integration: Does it Make Any Difference?" Regions and Regionalism in Europe. Ed. M. Keating. Cheltenham: Edgar Elgar 2004.

Kelly, Michael. "Pakistan Too Good to Miss." The Scotsman 10.10.2012, http://bit.ly/ 1HT5eWR. Accessed: 3.02.2015.

Kenealy, Daniel. "Commercial Interests and Calculated Compassion: The Diplomacy and Paradiplomacy of Releasing the Lockerbie Bomber." Diplomacy \& Statecraft Vol. 23, No. 2, 2012.

Kuznetsov, Alexander. Theory and Practice of Paradiplomacy: Subnational Governments in International Affairs. New York: Routledge 2015.

Laitin, David. "National Identities in the Emerging European State." Minority Nationalism and the Changing international Order. Ed. M. Keating, J. McGarry. Oxford: Oxford University Press 2001.

Lecours, Andre. "Political Issues of Paradiplomacy: Lessons from the Developed World." The paper presented in the Clingendael Discussion Papers in Diplomacy at the Clingendael Institute in the Hague in 2008, http://bit.ly/1908Y9t. Accessed: 7.02.2015.

Manan, Abdul. "Governor Punjab Chaudhry Sarwar Resigns after Making Anti-Govt Remarks." The Express Tribune 29.01.2015, http://bit.ly/1zxSIF5. Accessed: 3.02.2015.

Marshall, Chris. "Scots Universities Criticise UK Immigration Laws." The Scotsman 12.02.2013, http://bit.ly/1A232XF. Accessed: 7.02.2015. 
Mathews, Jessica T. “Power Shift.” Foreign Affairs Vol. 76, No. 1, 1997.

McLauglin, Martyn. “PM 'Concern' over Scot on Death Row for Blasphemy.” The Scotsman 30.01.2014, http://bit.ly/1DBbso5. Accessed: 30.01.2015.

Moreno, Luis. "Local and Global: Mesogovernments and Territorial identities.” Nationalism and Ethnic Politics Vol. 5, No. 3-4, 1999: 61-75.

Palmer, Roseanne. Devolution, Asymmetry and Europe: Multi-Level Governance in the United Kingdom. Brussels: Peter Lang 2008.

Peterkin, Tom. "Record 'Proves Alex Salmond Kowtowed over Dalai Lama' Visit." The Scotsman 9.08.2012, http://bit.ly/1EOrBdm. Accessed: 7.02.2015.

Sevastupolo, Demetri. “Alex Salmond Slams UK Decision on Visa of 2 Chinese Teacher." The Financial Times 6.11.2013, http://on.ft.com/1ztd5o7. Accessed: 7.02.2015.

Soldatos, Panayotis. "An Explanatory Framework for the Study of Federated States as Foreign-Policy Actors." Federalism and International Relations. The Role of Subnational Units. Ed. H. Michelmann, P. Soldatos. Oxford: Oxford University Press 1990.

Sorensen, Georg. “Globalization and the Nation-State.” Comparative Politics. Ed. D. Caramani. Oxford: Oxford University Press 2008.

Szmigiel, Katarzyna. Regionalne po co i z kim? Relacje międzynarodowe polskich województw, Warszawa: Geoprofit 2009.

Tatham, Michael. "With or Without You? Revisiting Territorial State-Bypassing in EU Interest Representation.” Journal of European Public Policy Vol. 17, No. 1, 2010.

The European and External Relations Committee. Written Evidence From Philip Morgan (Ex First Secretary (Scottish Affairs)), http://bit.ly/1yjDHUu. Accessed: 3.02.2015.

The House of Commons Foreign Affairs Committee. Foreign Policy Considerations for the UK and Scotland in the Event of Scotland Becoming an Independent Country. The Sixth Report of Session 2012-13 Report together with the formal minutes, oral and written evidence 23.04.2013, http://bit.ly/1BUrpTK. Accessed: 4.02.2015.

The Scottish Government. India Plan. Edinburgh 2010, http://bit.ly/1yL9o8w. Accessed: 7.02.2015.

. Pakistan Plan. Edinburgh 2010, http://bit.ly/1yUtiz3. Accessed: 7.02.2015.

. Scotland's International Framework. Edinburgh: APS Group Scotland 2012.

. Working with China. A Five Year Strategy for Engagement between Scotland and the People's Republic of China. Edinburgh: APS Group Scotland 2012.

Tomaszewski, Krzysztof. Regiony w procesie integracji europejskiej. Kraków: Oficyna Ekonomiczna Grupa Wolters Kluwer 2007. 
Visit Britain. Trends in visits, nights, and spend to Scotland by visitors from overseas 2013, http://bit.ly/1FjuArO. Accessed: 7.02.2015.

Visit Scotland. Scotland. The Key Facts on Tourism in 2013, http://bit.ly/1ztnMqO Accessed: 7.02.2015.

Wolff, Stefan. "Paradiplomacy: Scope, Opportunities and Challenges." The Bologna Center Journal of International Affairs Vol. 10, 2007.

\section{Summary}

This article aims at presenting the activity of Scotland as a sub-state entity with reference to the field of its foreign policy. Its main assumption is that the concept of foreign policy has significantly changed in recent decades. The term most often used to describe this phenomenon is "paradiplomacy" understood as the involvement of non/state actors in autonomous diplomatic practices.

The article will argue that Scotland's activity within the international arena allows for it being considered as paradiplomatic, even protodiplomatic. It will be further demonstrated that the most important target of Scotland's paradiplomatic activity in Asia is China. The motivations of the Scottish paradiplomacy towards Asian countries can be seen on the regional, state and external levels. The article concludes that the relations between Scotland and the United Kingdom as regards foreign policy can be studied as bridging the complementary and discretion models.

Keywords: Scotland, Asia, devolution, foreign policy, paradiplomacy

\section{(PARA)DYPLOMACJA SZKOCJI WOBEC KRAJÓW AZJATYCKICH}

\section{Streszczenie}

Przedmiotem niniejszego artykułu jest opis aktywności Szkocji, jako podmiotu bez statusu państwa, w obszarze polityki zagranicznej. Podstawowym założeniem niniejszego artykułu jest stwierdzenie, że polityka zagraniczna uległa istotnym zmianom w ostatnich dekadach. Pojęciem, którego używa sie najczęściej do opisu tego zjawiska jest paradyplomacja, rozumiana jako zaangażowanie podmiotów niepaństwowych w autonomiczne działania dyplomatyczne.

W artykule stwierdzono, że aktywność Szkocji na arenie międzynarodowej pozwala na określenie jej mianem paradyplomacji, a nawet protodyplomacji. Wskazuje się, że 
najważniejszym celem paradyplomatycznej aktywności Szkocji w Azji są Chiny. Motywacje tych działań widoczne są na poziomie regionalnym, państwowym oraz zewnętrznym. Konkluzją artykułu jest także stwierdzenie, że wzajemne relacje między Szkocją i Zjednoczonym Królestwem w prowadzeniu polityki zagranicznej są formą pośrednią między modelem swobody i uzupełniania się.

Słowa kluczowe: Szkocja, Azja, dewolucja, polityka zagraniczna, paradyplomacja 
